\title{
MEDAN MAGNET
}

\author{
Abd. Aziz Ardiansyah, Resti Ardianti dan Nana \\ Pendidikan Fisika FKIP Universitas Siliwangi \\ Tasikamalaya Jawa Barat Indonesia 46115 \\ ardiansyah.aziz42@gmail.com
}

\begin{abstract}
Abstrak
Percobaan ini bertujuan untuk memahami materi mengenai medan magnet dan mampu menganalisis timbulnya medan magnet disekitar paku (Solenoida). Metode yang digunakan dalam percobaan ini adalah analisis rangkaian dengan mengamati medan magnet yang timbul. Percobaan dilakukan dengan menggunakan sebuah rangkian dengan paku yang dililiti kawat dan diberi tegangan oleh baterai sebesar 1,5 Volt. Data yang diperoleh dari percobaaan yang dilakukan pada rangkaian adalah menentukan seberapa kuat medan magnet yang dihasilkan dari lilitan kawat pada paku yang dialiri arus. Kesimpulan dari hasil percobaan menyatakan bahwa semakin banyak lilitan kawat tembaga pada paku, semakin kuat medan magnetnya. Sehingga menghasilkan tarikan yang lebih kuat. Hal ini menyebabkan semakin banyak jumlah staples yang dapat menempel pada paku (Solenoida).
\end{abstract}

Kata Kunci : Medan Magnet, Listrik

\section{Pendahuluan}

Dalam dunia pendidikan, salah satu mata pelajaran yang di anggap sulit dikalangan SMA adalah mata pelajaran fisika. Peserta didik menganggap bahwa fisika merupakan mata pelajaran yang membosankan karena selalu berhadapan dengan rumus-rumus yang membingungkan. Menurut Nana (2019) Fisika adalah pelajaran penting yang perlu pemahaman khusus, dan diperlukan sarana dan media yang mendukung pembelajaran. Oleh karena itu kami mengantisipasi dalam pembelajaran fisika supaya peserta didik lebih memahami konsep mengenai materi medan magnet, maka kami berinisiatif menggunakan metode eksperimen dalam pembealajaran, yaitu dengan menggunakan paku yang dililiti kawata berarus (Solenoida).
Pada awalnya orang-orang menemukan bahwa logam-logam tertentu dapat dibuat sebagai magnet. Kata "magnet" berasal dari nama daerah Magnesia di Asia kecil dimana ditemukan batu-batu yang tarikmenarik. Magnet inilah yang dapat menimbulkan medan magnet. Magnet ini ada yang berbentuk batang, jarum dan ladam. Batang magnet ini memiliki dua kutub yaitu kutub utara $U$ dan kutub selatan S. Dua kutub sejenis akan tolakmenolak dan dua kutub yang tidak sejenis akan tarik-menarik.

Medan magnet adalah suatu ruangan atau suatu daerah yang dipengaruhi oleh gaya magnetic. Magnet memiliki garis-garis atau pola-pola medan magnet yang keluar dari kutub utara dan masuk ke kutub selatan. 
Gelombang elektromagnetik merupakan interaksi antara medan listrik dan medan magnet. Selama abad ke delapan

belas, banyak filsuf alam yang mencoba menemukan hubungan antara listrik dan magnet. Muatan listrik yang stasioner dan magnet tampak tidak saling mempengaruhi. Tetapi pada tahun 1820, Hans Christian Oersted (1777-1851) menemukan bahwa ketika jarum kompas diletakkan di dekat kawat berarus listrik, jarum mengalami penyimpangan. Apa yang ditemukan Oersted adalah bahwa arus listrik menghasilkan medan magnet (Giancoli,2001:136).

Salah satu contoh medan magnet yang ditimbulkan oleh arus listrik adalah selonoida. Selonoiadal adalah nama lain dari kumparan yang dipanjangkan, seperti pada gambar di atas. Kuat medan magnet pada titik yang berada di pusat sumbu selonoida memenuhi persamaan berikut.

Rumus induksi magnetik ditengah solenoid :

$$
B=\frac{\mu_{0} \text { i N }}{L}
$$

Rumus induksi magnetik di ujung solenoid

$$
B=\frac{\mu_{0} \text { i N }}{2 L}
$$

Alat dan Bahan yang digunakan daintaranya: Paku Ukuran $12 \mathrm{~cm}$ (1 Buah), Paku Ukuran $8 \mathrm{~cm}$ (1 buah), Kabel (kawat tembaga secukupnya, Staples (secukupnya), Baterai 1,5 volt (ukuran D/AA) 1 buah, Kompas 1 buah.

Langkah kerja yang dilakukan pada percobaan medan magnet ini yaitu melilitkan kawat tembaga pada paku berukuran $12 \mathrm{~cm}$ (usahakan serapat mungkin) dengan variasi 10 lilitan, tempelkan ujung-ujung tembaga pada baterai dan tunggu beberapa saat, dekatkan steples pada paku. Amati apa yang terjadi, sekarang tambahkan jumlah lilitan dengan variasi 15, 20, 25, 30 pada paku dan amati apa yang terjadi saat bagaimana pengaruh penambahan lilitan tersebut, dengan menggunakan kaidah tangan kanan, analisis mana yang menjadi kutub selatan dan kutub utara magnet yang dihasilkan pada percobaan, cek kutub magnet dengan menggunakan kompas, dan lakukan langkah kerja yang sama seperti pada paku berukuran $8 \mathrm{~cm}$.

Pada awalnya orang-orang menemukan bahwa logam-logam tertentu dapat dibuat sebagai magnet. Kata "magnet" berasal dari nama daerah Magnesia di Asia kecil dimana ditemukan batu-batu yang tarikmenarik. Magnet inilah yang dapat menimbulkan medan magnet. Magnet ini ada yang berbentuk batang, jarum dan ladam. Batang magnet ini memiliki dua kutub yaitu kutub utara $U$ dan kutub selatan S.

Magnet memiliki dua buah kutub magnet yaitu kutub utara dan kutub selatan magnet. Dua kutub sejenis akan tolakmenolak dan dua kutub yang tidak sejenis akan tarik-menarik. Fenomena itu terjadi akibat adanya medan magnet. Seperti yang terlihat pada gambar di bawah ini.

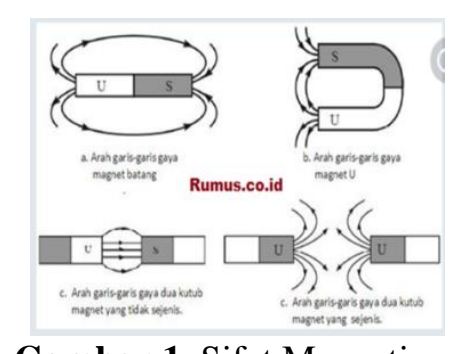

Gambar 1. Sifat Magnetic

Fenomena itu terjadi akibat adanya medan magnet. Medan magnet adalah daerah atau ruang di sekitar magnet dimana magnet lain atau benda lain yang mudah dipengaruhi magnet akan mengalami gaya 
magnetik jika diletakkan dalam ruang tersebut.

Magnet memiliki garis-garis atau pola-pola medan magnet yang keluar dari kutub utara dan masuk ke kutub selatan. Seperti yang terlihat pada gambar.

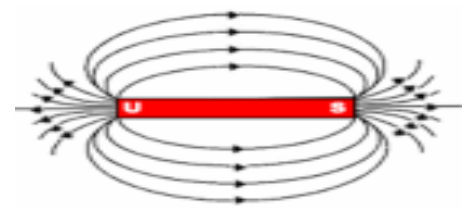

Gambar 2. Garis-garis Medan Magnet

Medan magnet dapat ditimbulkan dari kawat beraruslistrik. Pada tahun 1820 seorang ilmuan Denmark Hans Christian Oersted (1777-1857) menemukan suatu gejala yang menarik. Dalam percobaannya, ia menggunakan sebuah kompas jarum untuk menunjukkan bahwa ketika arus listrik mengalir pada seutas kawat, jarum kompas yang diletakkan pada daerah medan magnetik yang dihasilkan oleh kawat berarus menyebabkan jarum kompas menyimpang dari arah utaraselatan.Kemudin disimpulkan bahwa di sekitar kawat berarus timbul medan magnet. Medan magnet oleh kawat berarus inilah yang dinamakan dengan induksi magnet.

Induksi magnet merupakan besran vector arahnya dapat ditentukan dengan menggunakan kaedah tangan kanan. Seperti gambar di bawah. Ibu jari sebagai arah arus I dan empat jari lain sebagai arah induksi magnet B. Sedangkan besar induksi magnetnya dipengaruhi oleh kuat arusnya I, jarak titik ke penghantar dan bentuk penghantarnya.
Arah Induksi Magnetik di Sekitar Kawat Berarus Listrik. Cara menentukan arah garis medan-medan magnet di sekitar kawat berarus listrik adalah dengan menggunakan kaidah putaran tangan kanan yaitu sebagai berikut.

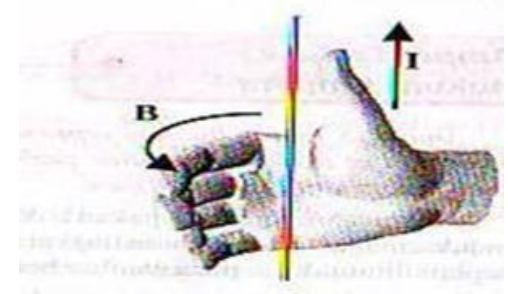

Gambar 3. Kaidah Tangan Kanan pada Kawat Lurus Berarus

Genggam kawat lurus dengan tangan kanan sedemikian hingga ibu jari menunjukkan arah kuat arus listrik. maka arah putaran keempat jari yang dirapatkan akan menyatakan arah lingkaran garisgaris medan magnetic. Atau, apabila kawat berbentuk lingkaran maka arah putaran keempat jari yang dirapatkan akan menunjukkan arah putaran arus listrik, demikian sehingga ibu jari menyatakan arah garis-garis medan magnetic.

\section{Induksi Magnet di dekat kawat lurus panjang berarus}

Contoh medan magnet yang ditimbulkan oleh arus listrik adalah kawat lurus panjang berarus, kawat melingkar berarus dan pada selonoida.

Kawat Lurus Panjang Berarus

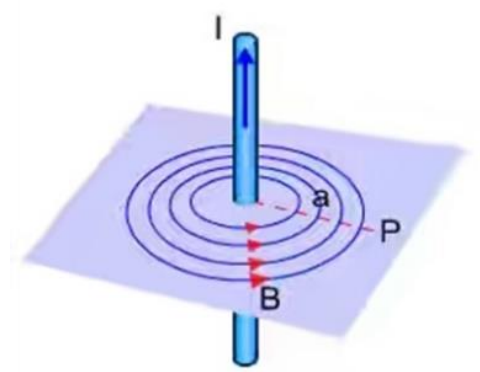

Gambar 4. Kawat Lurus Panjang Berarus 
Induksi magnet di sekitar kawat lurus panjang sebanding dengan kuat arus I dan berbanding terbalik dengan jaraknya $a$. Konstanta pembandingnya adalah $\frac{\mu_{0}}{2 \pi}$. Seperti gambar. Perhatikan persamaan berikut

$$
\mathrm{B}=\frac{\mu_{0} I}{2 \pi a}
$$

Dengan $\mathrm{B}$ adalah induksi magnet di titik $\mathrm{P}$ $\left(\mathrm{wb} / \mathrm{m}^{2}\right)$, I adalah kuat arus listrik (A), a adalah jarak titik $\mathrm{P}$ ke kawat $\left((\mathrm{m}), \mu_{0}=\right.$ permeabilitas hampa $\left(4 \pi \times 10^{-7} \mathrm{wb} / \mathrm{Am}\right)$.

Kawat Melingkar Berarus

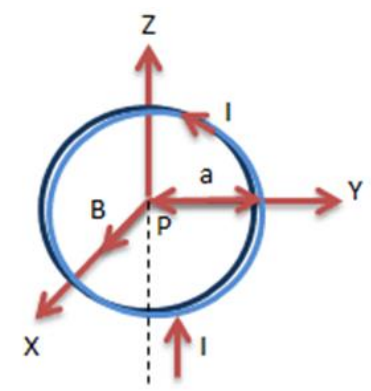

Gambar 5. Kawat Melingkar Berarus

Perhatikan gambar, sebuah kawat dilingkar-lingkarkan kemudian dialiri arus, jari-jari a dan terdapat N lilitan. Sesuai kaidah tangan kanan, induksi magnet dipusat lingkaran $\mathrm{P}$ arahnya ke sumbu $\mathrm{X}$ positif.

Besarnya induksi magnet sebanding dengan kuat arus I dan berbanding terbalik dengan a. Konstanta pembandingnya $\frac{\mu_{0}}{2}$

Salah satu contoh besar induksi magnetic adalah pada kawat selonoida berarus. Selonoiadal adalah nama lain dari kumparan yang dipanjangjan, seperti gambar pada gambar di atas.Kuat medan magnet pada titik yang berada di pusat sumbu selonoida memenuhi persamaan berikut. Rumus induksi magnetik ditengah solenoid :

$$
B=\frac{\mu_{0} \text { i N }}{L}
$$

Rumus induksi magnetik di ujung solenoid

$$
B=\frac{\mu_{0} \text { i N }}{2 L}
$$

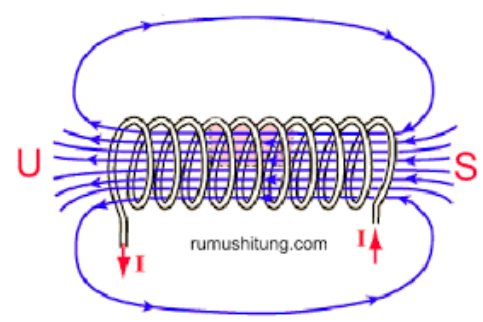

Gambar 6 kawat selonoida berarus

Pada kasus solenoida, arus $i$-nya berputar sehingga untuk memudahkan kaidah tangan kanan, arah putaran keempat jari yang dirapatkan menunjukkan arah putaran arus, sedang arah ibu jari menunjukkan arah garis-garis medan magnetiknya. Ketika sebuah solenoida dialiri arus listrik maka garis-garis medan magnetik yang dihasilkan mirip seperti magnet batang, dimana garis gaya magnet akan keluar dari ujung ibu jari (kutub utara) dan masuk ke pangkal ibu jari (kutub selatan).

Untuk membuktikan penjelasan secara teoritis maka dilakukan percobaan dengan alat dan bahan yang digunakan daintaranya: Paku Ukuran $12 \mathrm{~cm}$ (1 Buah), Paku Ukuran $8 \mathrm{~cm}$ (1 buah), Kabel (kawat tembaga secukupnya, Staples (secukupnya), Baterai 1,5 volt (ukuran D/AA) 1 buah, Kompas 1 buah.

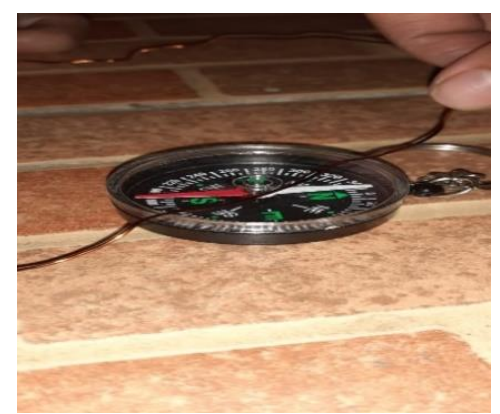

Gambar 7. Percobaan Oersted 


\section{Metode Penelitian}

Metode yang digunakan dalam percobaan ini berupa eksperiment secara berulang sehingga menghasilkan data yang valid.

\section{Hasil dan Pembahasan}

Data yang diperoleh dari hasil eksperimen atau percobaan dilihat dari aspek keterampilan proses sains yaitu: pengamatan, pelaksanaan penelitian, pengkomunikasian, peramalan, dan penyimpulan. Percobaan dilakukan masing-masing sebanyak lima kali, baik pada paku berukuran $8 \mathrm{~cm}$ maupun pada paku berukuran $12 \mathrm{~cm}$, keduanya dilakukan secara bergantian.

Berdasarkan hasil percobaan dapat diambil data sebgai berikut:

Tabel 1. Data percobaan dengan ukuran paku $8 \mathrm{~cm}$.

\begin{tabular}{|c|c|c|}
\hline \multirow{2}{*}{$\begin{array}{c}\text { Jumlah } \\
\text { Lilitan }\end{array}$} & Bahan Uji & \multirow{2}{*}{$\begin{array}{c}\text { Ukuran } \\
\text { Paku }\end{array}$} \\
\hline & Steples & \\
\hline 10 & 1 & $8 \mathrm{~cm}$ \\
\hline 15 & 3 & $8 \mathrm{~cm}$ \\
\hline 20 & 6 & $8 \mathrm{~cm}$ \\
\hline 25 & 7 & $8 \mathrm{~cm}$ \\
\hline 30 & 8 & $8 \mathrm{~cm}$ \\
\hline
\end{tabular}

Tabel 2. Data percobaan dengan ukuran paku $12 \mathrm{~cm}$.

\begin{tabular}{|c|c|c|}
\hline \multirow{2}{*}{$\begin{array}{l}\text { Jumlah } \\
\text { Lilitan }\end{array}$} & Bahan Uji & \multirow{2}{*}{$\begin{array}{c}\text { Ukuran } \\
\text { Paku }\end{array}$} \\
\hline & Steples & \\
\hline 10 & 2 & $12 \mathrm{~cm}$ \\
\hline 15 & 3 & $12 \mathrm{~cm}$ \\
\hline 20 & 4 & $12 \mathrm{~cm}$ \\
\hline 25 & 6 & $12 \mathrm{~cm}$ \\
\hline 30 & 7 & $12 \mathrm{~cm}$ \\
\hline
\end{tabular}

Untuk mendapatkan data tersebut maka dilakukan percobaan dengan menggunakan alat dan bahan daintaranya: Paku Ukuran $12 \mathrm{~cm}$ (1 Buah), Paku Ukuran $8 \mathrm{~cm}$ (1 buah), Kabel (kawat tembaga secukupnya, Staples (secukupnya), Baterai 1,5 volt (ukuran D/AA) 1 buah, Kompas 1 buah.

Setelah alat dan bahan terkumpul maka dilakukanlah percobaan yang memiliki langkah-langkah berikut: (1) dengan melilitkan kawat tembaga pada paku berukuran $12 \mathrm{~cm}$ (usahakan serapat mungkin) dengan variasi 10 lilitan; (2) tempelkan ujung-ujung tembaga pada baterai dan tunggu beberapa saat; (3) dekatkan steples pada paku. Amati apa yang terjadi, sekarang tambahkan jumlah lilitan dengan variasi 15, 20, 25, 30 pada paku dan amati apa yang terjadi saat bagaimana pengaruh penambahan lilitan tersebut, dengan menggunakan kaidah tangan kanan, analisis mana yang menjadi kutub selatan dan kutub utara magnet yang dihasilkan pada percobaan, cek kutub magnet dengan menggunakan kompas, dan lakukan langkah kerja yang sama seperti pada paku berukuran $8 \mathrm{~cm}$.

Hasil rangkaian percobaanya terlihat pada gamabar

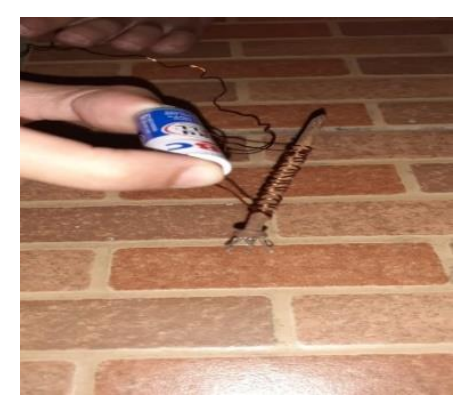

Gambar 8. Rangkaian Percobaan pada Solenoida

Hasil analisis dari tabel tersebut adalah : (1) Paku yang panjangnya $8 \mathrm{~cm}$, ketika jumlah lilitan pada paku sebanyak 10 
lilitan maka steples yang menempel adalah 1 saja, jika jumlah lilitan 15 maka steples yang menempel atau terangkat berjumlah 3 buah, jika jumlah 20 maka steples yang menempel berjumlah sebanyak 6 buah, jika jumlah lilitan 25 maka steples yang menempel sebanyak 7 buah, dan jika jumlah lilitan 30 maka steples yang menempel sebanyak 8 buah. (2) ketika paku dengan panjang $12 \mathrm{~cm}$ memiliki jumlah lilitan 10 maka steples yang menempel berjumlah 2 buah, jika dengan jumlah lilitan 15 maka steples yang menempel 3 buah, jika dengan jumlah lilitan 20 maka steples yang menempel berjumlah 4 buah, jika dengan jumlah lilitan 25 maka steples yang menempel berjumlah 6 buah dan jika dengan jumlah lilitan sebanyak 30 maka steples yang menempel sebanyak 7 buah.

Hasil analisis ini sesuai dengan teoritis yaitu ketika jumlah lilitan kawat pada selonoida banayak maka besar medan magnet yang dihasilkan akan lebih besar karena besar medan magnet berbanding lurus dengan jumlah lilitan kawat. Yang memiliki persamaan sebagai berikut:

Rumus induksi magnetik ditengah solenoid :

$$
B=\frac{\mu_{0} \text { i N }}{L}
$$

Rumus induksi magnetik di ujung solenoid

$$
B=\frac{\mu_{0} \text { i N }}{2 L}
$$

Kemudian dilakukan percobaan dengan menggunakan kompos untuk membuktikan percobaan yang dilakukan Oersted. Ketika kompas diletakkan didekat selonoida berarus maka jarum kompas tersebut menyimpang maka hal ini sesuai dengan teori Oersted yaitu bahwa jika kawat tidak dialiri arus listrik $(I=0)$ maka jarum listrik tidak menyimpang. Jika kawat dialiri arus listrik dari A ke B maka jarum magnet akan meyimpang ke kiri, sedangkan jika kawat dialiri listrik B ke A maka magnet akan menyimpang ke kanan. Dapat dilihat pada gambar dibawah bahwa jarum kompas tersebut benar-benar menyimpang. Ini artinya percobaan yang telah dilakukan berhasil dan sesuai dengan teori yang telah dikemukakan oleh Oersted.

\section{Simpulan}

Berdasarkan hasil percobaan dapat disimpulkan bahwa: (1) Semakin banyak lilitan kawat tembaga pada paku, semakin kuat medan magnetnya. Sehingga menghasilkan tarikan yang lebih kuat pula. Hal ini menyebabkan semakin banyak jumlah steples yang dapat menempel dan terangkat. (2) ketika kompas didekatkan pada paku yang diberikan arus maka jarum kompas tersebut terlihat menyimpang dapat disimpulkan bahwa percobaan yang dilakukan sesuai dengan percobaan Oersterd bahwa ketika kompas didekatkan dengan paku yang berarus maka kompas akan menyimpang. Hasil percobaan yang kami lakukan sesuai dengan percobaan yang dilakukan Oersted yaitu ketika paku didekatkan pada kompas, maka jarum kompasnya menyimpang ke arah utara. arah utara dapat diibaratkan dengan arah ibu jari (arah arus listrik) atau searah dengan katoda (+) baterai, dan kutub selatan sesuai dengan anoda (-) pada baterai. Ini menujukkan bahwa medan magnet memiliki arah uatara dan selatan yang mengarah keluar dan kedalam kutub. 


\section{Daftar Pustaka}

Anonym. (2013). Medan Magnet.

[Online].Tersedia :http://andryperma na06. blogspot.co.id/2013/04/medanmagnet.html. [14 November 2019].

Giancoli, D. C. 2001. Fisika Jilid 2.

Jakarta : Erlangga.

Halliday David,dkk.2010.Fisika Dasar

Edisi ke Tujuh Jilid 2 . Jakarta :

Erlangga.

Nana \& Pramono, H. (2019). Diffraction.

Upaya Peningkatan Kemampuan

Kognitif dan Komunikasi Ilmiah

Siswa kelas X MIA 1 SMA Negeri 1

Ciamis Menggunakan Mode

Pembelajaran Inquiry, 1, 1-10. 